\title{
THE EFFECT OF ACCOUNTABILITY AND TRANSPARENCY OF VILLAGE FUND MANAGEMENT
}

\author{
Yuhanis Ladewi ${ }^{1)}$,Taufiq Supriadi ${ }^{2)}$,Juska Meidy Enyke Sjam ${ }^{3)}$,Welly ${ }^{1)}$ \\ Agista $^{1)}$ and Hery Subowo ${ }^{4)}$ \\ ${ }^{1}$ Accounting study program Economics and Business Faculty \\ Palembang Muhammadiyah University \\ ${ }^{2}$ Lecturer STIE Dharma Bumiputera, Jakarta \\ ${ }^{3}$ Doctoral Study Program in Accounting, Faculty of Economics and Business, \\ Padjadjaran University, Bandung \\ ${ }^{4}$ Management Science Doctoral Program Postgraduate Program Jakarta State \\ University
}

\begin{abstract}
Purpose - The purpose of this study is to investigate and analyze the Effect of Accountability and transparency on the management of survey village funds in Merapi Selatan District and Pulau Pinang District, Lahat Regency. This research was conducted because there are phenomena associated with accountability and transparency in the management of village funds.

Design/methodology/approach - The methodology used in this study consists of the type of this research is descriptive and associative research. The variables in this study are Accountability, Transparency, and Village Fund Management. The population in this study were 23 villages in Merapi Selatan and Pulau Pinang Districts, each village consisting of 3 respondents. Total questionnaires were distributed as many as 69 questionnaires, because there are some limitations of the questionnaire returned as many as 33 questionnaires and were processed.

Findings - Based on the results of research conducted on all data obtained in 33 respondents in Merapi Selatan District and Pulau Pinang District, it was found that accountability significantly affected village fund management, while transparency did not significantly influence village fund management.

Practical Implications - This research shows that accountability determines each activity and the final results of village government implementation activities must be accountable to the village community in accordance with statutory provisions.
\end{abstract}


Originality/value - The test used in this research is the validity test, the reliability test, the classic assumption test, the hypothesis test, and the coefficient of determination test.

Keywords - village fund management, accountability, transparency.

\section{INTRODUCTION}

Village Financial Management is the whole activity which includes planning, implementation, administration, reporting and accountability of village finances (Permendagri RI No. 113 of 2014). Village finance must be managed based on the principles of transparency, accountability, participation and be carried out in an orderly and disciplined budget. Village finance is managed in a budget year of 1 January to 31 December (Wiratna, 2015: 27).

Accountability is a principle that determines that each activity and the final results of village government implementation activities must be accountable to the village community in accordance with statutory provisions. (Law No.6 of 2014 article 19). Accountability that must be used by public sector organizations, namely: first, honesty and legal accountability, honesty or accountability (Accountability for probity) associated with avoiding misuse of position (Abuse of power).

Transparency is to provide open and honest financial information to the community based on the consideration that the public has the right to openly and comprehensively acknowledge the government's responsibility in managing the resources entrusted to it and its compliance with laws and regulations (Abdul, 2008: 9, Law Republic of Indonesia 2014). Transparency can be measured by Informativeness, Openness and Disclosure (Mardiasmo: 2009, Muindro: 2008)

Some phenomena that occur related to village fund management, as stated by Ajiep Padindang (2017), said that the management of village funds is not yet accountable and there are overlapping regulations and the management is still complicated. The three causes of misappropriation of village funds as revealed by the Governor of East Java Fira (2017), said that the lack of transparency, the lack of involvement of local communities and the accountability of programs that have been done. Similarly, what Fajri Azhari (2017) met with asked law enforcers to audit and investigate the realization of the use of village funds because their use is not transparent, thus potentially being misused by village officials.

Vol. 28, No. 2 August 2020

(C) Centre for Indonesian Accounting and Management Research Postgraduate Program, Brawijaya University 
La Asri (2017) dan Ganjar Pranowo (2017) said the planning process of village government activities, especially in 2015 and 2016 was not transparent such as boat mooring and farm roads along the two kilometers, but in fact the realization of the farm road work was only about one kilometer, as well as boat moorings that were considered unfinished and instead made house foundations. The same thing was stated by Setia Untung Arimuladi (2017) saying that the village head in managing village funds is not transparent and is not supported by adequate evidence, the construction or procurement of goods or services is not in accordance with specifications. Thjojo Kumolo (2017) said that currently there are many inefficient, effective, transparency and low accountability of village fund management, so that the police are involved in monitoring especially in the case of investigations if there are problems in managing village funds that deviate by the village head.

Political Observer Arif Susanto (2017), said that management and villages in East Java are still poor, resulting in arrest operations related to village funds. The incident shows that there are still village heads who have not used village funds properly and are not managed according to government regulations. The same thing stated by Pahala Nainggolan (2017), said that there were 300 reports about poor management of village funds and that management was still overlapping between ministries, so that government institutions related to village fund management were tossing responsibilities. Based on information from the Corruption Eradication Commission Budi, said there were 14 problems in the allocation of village funds that the distribution of village funds in PP No. 22 of 2015 is not enough transparency and is only based on the basis of equity. The arrangement for the distribution of fixed income for village officials from the village fund budget, regulated in PP No. 43 of 2014 lack justice.

Based on information from interviews with village officials in Kec. Merapi Selatan and Kec. Pulau Pinang said that the management of village funds had not been carried out in an accountable and transparent manner as the village government could not make and present accountability reports and there were still villages that did not yet have a bulletin board on the APBDesa as a form of transparency to the village community.

This research was conducted referring to previous research conducted by Rita and Nurfitriana (2011). The results of the study showed that accountability, transparency, community participation, efficiency and effectiveness simultaneously affected the performance of budgeting based on performance. Furthermore Asrida (2012) conducted a study with the results that Accountability is more influential on the performance of budgeting in the Bireuen District Government when compared to transparency. Research results by Risya and Idang (2017) Accountability affect the management of village

Vol. 28, No. 2 August 2020

(C) Centre for Indonesian Accounting and Management Research Postgraduate Program, Brawijaya University 
funds at the Riau Provincial Government Agency. Previous research conducted by Ni Luh and Ni Made (2017) results of the research are both partially and simultaneously accountability, transparency and budgetary participation have a positive effect on budget performance.

\subsection{Problem Formulation}

Based on the background that has been described previously, the formulation of the problem in this study are:

a. How the influence of accountability on the management of village funds

b. How the influence of transparency on the management of village funds.

\subsection{Research Objectives}

Based on the formulation of the problem, the purpose of this study is to:

a. Knowing and analyzingthe influence of accountability on the management of village funds

b. Knowing and analyzingthe influence of transparency on the management of village funds.

\section{Literature review}

\subsection{Accountability}

Accountability is responsible for the management of resources and the implementation of policies entrusted to reporting entities in achieving goals that have been set periodically (Abdul, 2008: 9). Accountability is understood as the holder of the mandate (agent) to give responsibility, present, report, and disclose all activities and activities that are the responsibility of the party that gives the mandate (principal) who has the right and authority to hold them accountable (Mardiasmo, 2009: 18).

Accountability that is responsible for the management of resources and the implementation of policies entrusted to reporting entities in achieving goals that have been set periodically (Dedi, 2010: 29). Accountability or accountability (accountability) is a form of obligation of a person (leader / official) to ensure that the duties and obligations undertaken have been carried out in accordance with applicable regulations (Wiratna, 2015: 28). Accountability is the responsibility to the public for every activity carried out (Muindro, 2008: 20). Accountability that is responsible for the management and implementation of resource policies in achieving goals (Melia, et al, 2011: 25). Based on the opinion of Abdul (2008), Wiratna (2015), Muindro (2008), Melia, et al, (2011), it can be concluded that accountability is an accountability of someone who has been entrusted to carry out and account for tasks and

Vol. 28, No. 2 August 2020

(C) Centre for Indonesian Accounting and Management Research Postgraduate Program, Brawijaya University 
activities clearly and report, presents / gives results.Measurement of accountability in this study is honesty and legal accountability, managerial accountability, program accountability, policy accountability. (Mahmudi (2007) and Mardiasmo (2009))

\subsection{Transparency}

Transparency, namely providing financial information that is open and honest to the community based on the consideration that the public has the right to openly and comprehensively know about the government's responsibility in managing the resources entrusted to him and his compliance with legislation (Dedi, 2010: 30). Transparency means in running the government, expressing material things on a regular basis to parties who have an interest for it, in this case the wider community (Mardiasmo, 2009: 18). Transparency is providing financial information that is open, honest, comprehensive, to stakeholders (Melia, et al, 2011: 25).

Transparency is a principle of openness that allows the public to know and get access to the widest possible information about regional finances (Merdiyanto and Fadel, 2009: 37). Based on the opinions of Deddi (2010), Mardiasmo (2009), Melia, et al (2011), Merdiyanto and Fadel (2009), it can be concluded that transparency is an information that is given accurately, clearly, and overall to the information user so that the information provided can be understood properly and does not cause misunderstanding between the party providing information and the wearer. Measurement of transparency used by researchers, namely: Informative, Openness and Disclosure.

\subsection{Village Fund Management}

Regional financial management is the overall activity that includes planning, implementation, administration, reporting and supervision of regional finances (Abdul, 2007: 330). Village financial management is the whole activity which includes planning, implementation, administration, reporting and accountability as well as regional financial oversight (Baldric, 2007: 12). Regional lease management is managing regional finances running efficiently and effectively in accordance with applicable laws and regulations and properly processed by local governments (Beni, 2016: 150).

Regional financial management is the whole activity which includes planning, implementation, administration, reporting, accountability, regional finance (Permendagri No. 113 2014). Based on the opinion of Abdul (2007), Baldric (2015), Beni (2016), it can be concluded that village fund management

Vol. 28, No. 2 August 2020

(C) Centre for Indonesian Accounting and Management Research Postgraduate Program, Brawijaya University 
is all village fund management activities managed by the trustee to manage all village funds that have been transferred by the government to the village to realize the community. the prosperous. Measurement of village fund management in this study are: Planning, implementation, administration, reporting and accountability (Tirasmart (2017), Wiratna (2015), Baldric (2015), Beni (2016)).

\subsection{Framework}

Accountability is understood as the obligation of the trustee (Agent) to provide responsibility, present, report, and disclose all activities and activities that are his responsibility to the trustee (principal) who has the right and authority to hold accountable (Mardiasmo, 2009: 18). Accountability is the responsibility to the public for every activity carried out (Abdul, 2007: 22). Transparency is to provide open and honest financial information to the community based on the consideration that the public has the right to openly and comprehensively know about the government's responsibility in managing the resources entrusted to him and his compliance with laws and regulations (Dedi, 2012: 30).

This research was conducted referring to previous research conducted by Rita and Nurfitriana (2011). The results of the study showed that accountability, transparency, community participation, efficiency and effectiveness simultaneously affected the performance of budgeting based on performance. Furthermore Asrida (2012) conducted a study with the results that Accountability is more influential on the performance of budgeting in the Bireuen District Government when compared to transparency. Research results by Risya and Idang (2017) Accountability affect the management of village funds at the Riau Provincial Government Agency. Previous research conducted by Ni Luh and Ni Made (2017) results of the research that is both partially and simultaneously accountability, transparency and budgetary participation have a positive effect on budget performance.

Accountability

Wiratna (2015), Abdul (2008), Tim

Redaksi (2008), Muindro (2008),

Mardiasmo (2009), Melia dkk

(2011), Abdul (2004), Mahmudi

(2007), Dedi (2010), Deddi (2006)

Transparency

Abdul (2008), Dedi (2010),

Vol. 28

Mardiasmo (2009), Melia dkk

(C) Cen (2011), Deddi (2006),

Cen Muindro(2008), Abdul (2007),

Postgr Muindro(2008), Merdiyanto dan

Fadel (2009)

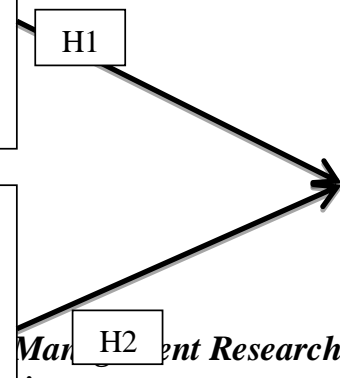

ity

Figure. 1 Framework
Village Fund Management Tirasmart (2017), Abdul (2007), Baldric (2015), Beni (2016) 


\subsection{Hypothesis}

Based on the description above, the hypothesis can be arranged as follows:

$\mathrm{H} 1$ : There is an influence of accountability on the partial management of village funds

$\mathrm{H} 2$ : There is an influence of transparency on the partial management of village funds

\section{Research Methodology}

\subsection{Types of research}

This type of research that will be used by this research is descriptive and associative research. Descriptive research is research conducted to find out the value of the variable accountability, transparency, and management of research village funds. Associative is research that aims to determine the effect of accountability and transparency on the management of village funds.

\subsection{Research Focus}

The focus of research is the things that are the center of attentionin research so that it will facilitate the research to determine which data is needed. The research variables include:

a. Accountability (X1) with indicators of legal accountability and honesty, managerial accountability, program accountability, policy accountability and financial accountability.

b. Transparency (X2) with informative indicators, disclosure and disclosure

c. Village fund management $(\mathrm{Y})$ with indicators of the planning stage, the implementation phase, the administration stage, the reporting stage and the accountability stage

\subsection{Research Sites}

The location of the study conducted by the author in the study of accountability and transparency in the management of village funds is located in villages located in Merapi Selatan District and Pulau Pinang District, Lahat Regency. The choice of location is based on consideration because the level of accountability and transparency in the management of village funds in the research location needs to be increased in order to support the realization of good governance in Merapi Selatan and Pulau Pinang Districts. South Merapi 
District consists of 9 villages with postal code 31471 and Pulau Pinang District consists of 14 villages with postal code 31461.

\subsection{Research Informants}

All populations will be examined by selecting respondents based on certain criteria, the criteria used are the apparatus and village fund management team chosen by the village head to carry out village fund management, namely the village head, the Village Secretary, the Village Treasurer and 2 Kasi programs, then each villages will be taken by 5 respondents. The population in this study were 23 villages in Merapi Selatan and Pulau Pinang Districts, each village consisting of 3 respondents. Total questionnaires were distributed as many as 69 questionnaires, because there are some limitations of the questionnaire returned as many as 33 questionnaires and were processed.

\subsection{Research Instruments}

The research instrument consisted of interviews and questionnaires, namely:

a. Questionnaire

Questionnaires are a way of collecting data using questionnaires or questionnaires about accountability, transparency and management of village funds

b. Interview

Interviews are a way of collecting data by holding direct responses to the object under study or to intermediaries who know the issues regarding accountability, transparency and management of village funds.

\subsection{Data collection and Data Analysis Techniques}

Thedata needed in this study were primary and secondary data. The data collection technique is questionnaire and interviews. Technical analysis in this research used is data test with validity and reliability test, classical assumption test, then hypothesis testing is conducted.Test data normality. Normality test aims to determine whether the confounding or residual variables have a normal distribution. In this test there are two ways that can be used to test the normality of the regression model, namely by graphical analysis (normal P-P plot) ( Duwi, 2013: 74).

Multicollinearity Test ,This test aims to prove the situation where between two or more independent variables in the regression model a perfect or near perfect linear relationship occurs. A good regression model should not find multicollinearity problems (Duwi, 2013: 59).

Heteroscedasticity Test, Heteroscedasticity test is performed to determine the circumstances in which the variance of residuals is unequal in the regression

Vol. 28, No. 2 August 2020

(C) Centre for Indonesian Accounting and Management Research Postgraduate Program, Brawijaya University 
model. A good regression model requires the absence of heteroscedasticity problems (Duwi, 2013: 60)

\section{a. Descriptive Statistical Analysis}

Statistical descriptive analysis provides a description or description of data that is seen from the minimum value, maximum value, mean value and standard deviation of each research variable. Statistical test results for accountability variables (X1), transparency (X2) and village fund management (Y) are processed using SPSS 23 from the variables of this study.

\section{b. Associative Analysis}

Associative is research that aims to determine the effect of accountability and transparency on the management of village funds. In this analysis will be tested on hypotheses,

\section{Hypothesis Test Design}

H01: Accountability Does not affect the management of village funds

Ha1: Accountability influences the management of village funds

H02: Transparency has no effect on village fund management

Ha2: Transparency affects the management of village funds

Critria: if $\mathrm{t}$ arithmetic $>\mathrm{t}$ table, then $\mathrm{HO}$ is rejected and accepts $\mathrm{Ha}$

\section{RESEARCH RESULT}

\subsection{Data Testing}

Based on the results of testing the validity of the questions for the variables of accountability, transparency and village fund management declared valid, because $r$ count $>r$ table or $r$ count greater than 0.361 . The reliability test results, the cronbach's alpha value of each variable is greater than rtabel (product moment), therefore, all statements of each variable are declared reliable.

\section{a. Normality test}

Indication of multicollinearity symptoms can be seen from the value of $\mathrm{R}$ Square (R2) normality with the P-P plot in this study assisted with SPSS 23 The results of the normality test can be seen in Figure 2 below: 


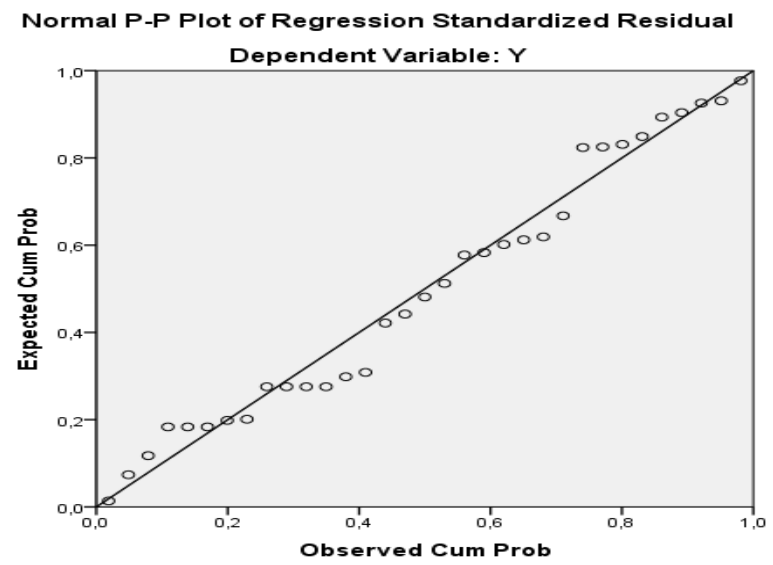

Source: Data Processing Results, 2018

Figure 2

Normality Test Results

Based on Figure 2 it can be concluded that the normal graph $\mathrm{P}$ P plot shows the points spread around the diagonal lines and the distribution follows the diagonal direction, the graph shows that the regression model is feasible because it meets the normality assumption.

\section{b. Multicollinearity Test}

The multicollinearity test in this study was assisted with SPSS 23 with the following results:

Table 2

Multicollinearity Test Results

Coefficients

\begin{tabular}{|cc|c|c|}
\hline \multirow{2}{*}{ Model } & \multicolumn{2}{|c|}{ Collinearity Statistics } \\
\cline { 3 - 4 } & (Constant) & Tolerance & VIF \\
\hline 1 & & \\
& X1 &, 249 & 4,018 \\
& X2 &, 249 & 4,018 \\
\hline
\end{tabular}

a. Dependent Variable: village fund management (Y)

Source: Data Processing Results, 2018

Vol. 28, No. 2 August 2020

(C) Centre for Indonesian Accounting and Management Research

Postgraduate Program, Brawijaya University 
Based on table 2 above the tolerance value of each variable> 0.1 and the VIF value $<10$, it can be concluded that there is no multicollinearity between the independent variables in the study.

\section{c. Heteroscedasticity Test}

Heteroscedasticity test with Scatterplot in this study was assisted with SPSS 23 with the following results:

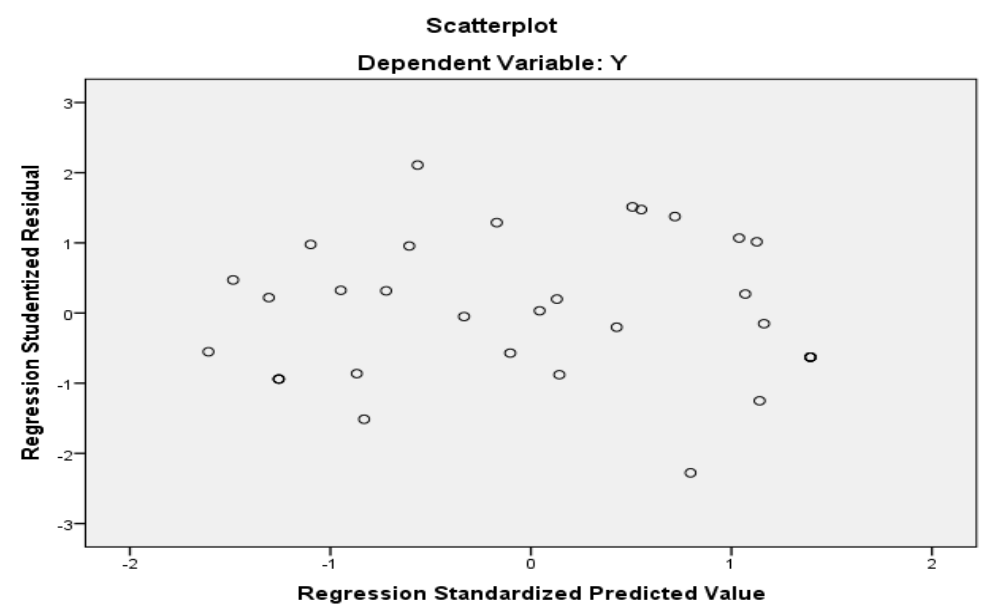

Source: Data Processing Results, 2018

Figure. 3

Hasil Uji Heteroskedastisitas (Scatterplot)

Based on Figure 3 between the predictive value of the dependent variable with the residual obtained the result of the absence of a clear pattern and the points spread above and below the number 0 on the $\mathrm{Y}$ axis, then there is no heteroscedasticity.

\section{d. Autocorrelation Test}

The Durbin Watson test in this study was assisted with SPSS 23 with the following results:

Table 3

Autocorrelation test results

Model Summary ${ }^{\mathrm{b}}$

\begin{tabular}{|l|r|r|r|r|r|}
\hline Model & $\mathrm{R}$ & $\mathrm{R}$ Square & $\begin{array}{r}\text { Adjusted } \\
\mathrm{R} \text { Square }\end{array}$ & $\begin{array}{c}\text { Std. Error of the } \\
\text { Estimate }\end{array}$ & Durbin-Watson \\
\hline 1 &, $658^{\mathrm{a}}$ &, 433 &, 395 & 3,82968 & 1,874 \\
\hline
\end{tabular}

Vol. 28, No. 2 August 2020

(C) Centre for Indonesian Accounting and Management Research Postgraduate Program, Brawijaya University 

a. Predictors: (Constant), X2, X1
b. Dependent Variable: Y

Source: Data Processing Results, 2018

Based on table 3 it is known that the value of DW is 1.887 , then this value will be compared with the value of the Durbin Watson table where the amount of data $n=33$ and the number of independent variables $K=3$ then obtained $\mathrm{dl}=1.32119$ the value of $\mathrm{du}=1.57703$ then the conclusion drawn $\mathrm{dL}$ $<$ DW < du. Then no conclusions can be drawn.

\subsection{Descriptive Statistical Analysis}

The statistical test results of accountability variables (X1), transparency (X2) and village fund management (Y) were processed using SPSS 23 from the variables of this study can be seen in table 1 .

Table. 1

Descriptive Statistics Variable

\begin{tabular}{|c|c|r|r|r|r|}
\hline & $\mathrm{N}$ & Minimum & Maximum & Mean & Std. Deviation \\
\hline Y & 33 & 40,00 & 50,00 & 44,9394 & 3,14185 \\
X2 & 33 & 42,00 & 59,00 & 52,4545 & 4,56269 \\
X1 & 33 & 59,00 & 72,00 & 64,3030 & 3,64422 \\
Valid & 33 & & & & \\
N (listwise) & & & & \\
\hline
\end{tabular}

Source: Data Processing Results, 2018

Overall, from the variables of accountability, transparency and management of village funds, accountability has the highest value compared to transparency and management of village funds, but the average value tends to approach the smallest value so that accountability is relatively low.

\subsection{Associative Analysis}

\section{a. Hypothesis testing}

$\mathrm{T}$ test is done by comparing the significance of tcount with ttable with the following conditions:

(a) $\mathrm{H} 0$ is accepted and $\mathrm{Ha}$ is rejected if $\mathrm{t}$ arithmetic $<\mathrm{t}$ table for $\mathrm{a}=0.05$

(b) $\mathrm{HO}$ is rejected and $\mathrm{Ha}$ is accepted if $\mathrm{t}$ arithmetic $>\mathrm{T}$ table for $\mathrm{a}=0.05$

To answer the question how is the influence of Accountability (X1) and Transparency (X2) on the management of village funds (Y), then the results are tested using the $t$ test, can be seen from table 4

\section{Table 4}

T Test Results (Coefficients ${ }^{\mathrm{a}}$ )

\begin{tabular}{|l|c|c|c|c|c|}
\hline Model & $\begin{array}{c}\text { Unstandardized } \\
\text { Coefficients }\end{array}$ & $\begin{array}{c}\text { Standardized } \\
\text { Coefficients }\end{array}$ & $\mathrm{T}$ & Sig. & $\begin{array}{c}\text { Collinearity } \\
\text { Statistics }\end{array}$ \\
\hline
\end{tabular}

Vol. 28, No. 2 August 2020

(C) Centre for Indonesian Accounting and Management Research

Postgraduate Program, Brawijaya University 


\begin{tabular}{|c|c|c|c|c|c|c|c|}
\hline & B & $\begin{array}{c}\text { Std. } \\
\text { Error }\end{array}$ & Beta & & & $\begin{array}{c}\text { Tolera } \\
\text { nce }\end{array}$ & VIF \\
\hline 1 (Constant) & 13,584 & 3,214 & & 4,227 &, 000 & & \\
\hline X1 & 501, & 158, & 874, & 3,171 & ,003 & 249 & $\begin{array}{r}4,01 \\
8\end{array}$ \\
\hline $\mathrm{X} 2$ &,- 176 & 183, &,- 265 &,- 963 & ,343 & ,249 & $\begin{array}{r}4,01 \\
8\end{array}$ \\
\hline
\end{tabular}

a. Dependent Variable: Y

Source: Data Processing Results, 2018

\section{b. Hypothesis test results}

a) Effect of Accountability (X1) on village fund management (Y)

Hypothesis test results show that the calculated $t$ value for the accountability variable is 3.171 while the value of $t$ table with a real level (a) of $0.05(5 \%)$ and $\mathrm{df}=\mathrm{n}-\mathrm{k}-1(33-2-1)=30$ is 2.042 . So it can be concluded that $\mathrm{H} 01$ is rejected and $\mathrm{Ha} 1$ is accepted because the value of $\mathrm{t}$ arithmetic 3.171> t table 2.042. Individual hypothesis test results for the accountability variable (X1) show that the variable significantly influences the village fund management variable $(\mathrm{Y})$

\section{b) The Influence of Transparency X2 on village fund management (Y)}

Hypothesis test results indicate that the calculated $t$ value for the Transparency variable (X2) of -0.963 while the value of ttable with a real level of $0.05(5 \%)$ and $\mathrm{df}=\mathrm{nk}-1(33-2-1)=30$ is equal to -0.963 while the value of $\mathrm{t}$ table with a real level of $0.05(5 \%)$ and $\mathrm{df}=\mathrm{nk}-1(33-2-1)=30$ is equal to 2,042. So it can be concluded that H01 is accepted and Ha1 is rejected because the $t$ value is $-0.963<t$ table 2.042. Individual hypothesis test results for the Transparency variable (X2) show that the variable does not significantly influence the variable management of village funds $(Y)$.

\section{DISCUSSION}

The results of this study were motivated since the enactment of Law no. 6 of 2014 concerning Funds originating from the APBN for every village in Indonesia, each village is given the authority to manage its own finances. Efforts to reform the bureaucracy are intensified to carry out comprehensive public sector financial management in achieving good governance. To manage such large funds, the village apparatus is required to be able to understand the procedures in management. If the apparatus understands every procedure in

Vol. 28, No. 2 August 2020

(C) Centre for Indonesian Accounting and Management Research Postgraduate Program, Brawijaya University 
management, it is expected that there will be no misuse of the budget, namely the existence of corruption which will harm the people.

The village apparatus must be able to account for every village fund management that is its responsibility, the village apparatus must also be able to act transparently and honestly in the management of village funds, so that researchers are interested in being able to know the effect of accountability and transparency on village fund management in villages in Merapi Selatan and Kecamatan Pulau Pinang, Lahat Regency.

\section{Effect of accountability (X1) on village fund management (Y) in Merapi Selatan District and Pulau Pinang District Lahat Regency}

Based on the results of the analysis and hypothesis testing conducted shows that accountability significantly influences the management of village funds. The results of this study indicate that accountability is a very important thing done by the village government in the management of the Village Fund. This is reinforced by the answers of respondents who answered very agree / very appropriate to the measurement of legal accountability and honesty in managing village funds, proving that the responsibility of the village government both to the community and the government above is an obligation of the village government to fulfill these responsibilities.

Good village fund management is management that can be accounted for starting from planning to reporting. In the results of this study it is also expected that the village government will comply with procedures and laws that apply in financial management. Village government compliance with procedures and laws will encourage the creation of avoidable waste and corruption management.

The performance of the village government in developing village fund programs has been well done, it is supported by the answers of respondents who answered agreed or according to managerial accountability measures. The results of research on program accountability, that the village government has prioritized the public interest in determining the village fund program, the village government has also taken into account the costs and benefits in determining the program.

The results of research on policy accountability show that every policy taken by the village government has been able to be accounted for, both the central government and the community. The results of research on financial accountability are strengthened by the answers of respondents who agree to each question provided. This research is in line with research conducted by Rita and Nurfitrianah (2011), Debi (2015), Putu and Yenni (2017), Risya and Idang (2017), Rita and Nurfitrianah (2011), Debi (2015) who say that accountability

Vol. 28, No. 2 August 2020

(C) Centre for Indonesian Accounting and Management Research

Postgraduate Program, Brawijaya University 
influences partially on regional financial management. The results of testing this hypothesis are consistent with the hypothesis stated by researchers that there is an effect of transparency on the management of village funds in the South Merapi District and Pulau Pinang District, Lahat Regency.

Accountability is understood as the obligation of the trustee (Agent) to provide responsibility, present, report and disclose all activities and activities that are his responsibility to the trustee. So the government is demanded to be able to increase accountability in an effort to encourage accountable management. Accountability is expected to improve the quality and performance of government agencies to become a government that is responsible and oriented to the public interest.

\section{The influence of transparency (X2) on the management of village funds (Y) in Merapi Selatan District and Pulau Pinang District of Lahat Regency.}

Based on the results of the analysis and hypothesis testing conducted that transparency does not significantly influence the management of village funds. One of the main elements in good financial management is transparency, since the government currently has the authority to make important decisions that affect many people, the government must provide complete information about what it is doing.

Provision of complete information regarding the work of the village head in decision making does not always indicate that the management of the village fund is good, it was stated by one of the village heads in Merapi Selatan and Pulau Pinang Subdistricts who stated that openness in providing information about the work of the village head such as fund management villages are not too high priority because ultimately the village head will determine the decisions in managing funds from planning to accountability.

The results of the respondent's questionnaire regarding informative indicators that if the village government makes it easy for the community or other village apparatus, starting from the planning stage to accountability for being able to access managed financial information, does not always indicate good village fund management, as revealed by the head of the salamat village namely if the village government is open in providing information to the community and village officials, it will make the management of village funds undirected because village officials and the community do not understand the delivery of information, so that the decision making is only done by the village head. This is supported by the answers of respondents who answered that the village government was still closed and complicated in the questions provided. 
The results of research on information disclosure that if the village government is open in providing documents on the use of village funds, the community will know the clarity of the budget used, it will make the community and village government make good management. Providing documents for the use of village funds also does not always indicate that village fund management is good.

This research is not in line with research conducted by Rita and Nurfitrianah (2011), Debi (2015), Putu and Yenni (2017), Risya and Idang (2017), Rita and Nurfitrianah (2011), Debi (2015), Gerryan (2017) ) which says that transparency has a partial effect on the management of regional finances. The results of testing this hypothesis are not consistent with the hypothesis stated by the researchers that there is an effect of transparency on the management of village funds in Merapi Selatan District and Pulau Pinang District, Lahat Regency, but it is consistent with the answers of many respondents who agree agree if the provision of information is closed from the measurement of transparency.

\section{Conclusion}

Based on the researcher's hypothesis which states that:

1. There is an influence of accountability on the management of village funds in the villages of South Merapi District and Pulau Pinang District, Lahat Regency. While the researcher can conclude that the results of the study and the hypothesis of the researchers have the same results, namely there is an influence of accountability on the management of village funds in the District of Merapi Selatan and Kecamatan Pinang, Lahat Regency

2. There is an influence of transparency on the management of village funds in Merapi Selatan District and Pulau Pinang District, Lahat Regency. While H2 is not the same as the results of the study, the results of the study stated that there was no effect of transparency on the management of village funds in Merapi Selatan District and Pulau Pinang District, Lahat Regency, so it was not in line with the researcher's hypothesis. 


\section{REFERENCES}

Abdul Hafiz Tanjung. 2008. Regional Government Accounting (Issue 3). Bandung: Alfabeta.

Abdul Halim. 2007. Regional Financial Accounting. Jakarta: Salemba Empat.

Ajiep Padindang. 2017. Dpd Value of Village Fund Management Less Accountable. Via https://news.detik.com/berita/d-3563210/dpd-valuemanagement-fund-vilage-less-accountable-this-word-mendes. accessed on 06-11-2017.

Arif Susanto. 2017. Observation There Are Three Problems of Village Funds. Through http: //www.onenews.com/national/446095-observation-havetree-problem-fund-village.html. accessed on06-11-2017.

Asrida. 2012. The Influence of the Application of the Principle of Financial Accountability and Transparency on the Performance of Budgeting in the Bireuen Regency Government. Nationality Journal 1 (1). Through http://jurnal.ptkb-aceh.ac.id/index.php/stie/article/view/33/5. accessed on 06-11-2017.

Baldric Siregar. 2017. Public sector accounting. Jakarta: Upp Stim Ykpn.

Beni Pekei. 2016. Concepts and Effectiveness Analysis of Financial Management in the Era of Autonomy. Jakarta: Taushia.

Budi. 2015. Kpk Finds 14 Problems in Village Fund Allocation. Via https://news.okezone.com/read/2015/06/12/337/1164638/kpk-find-14problems-in-alocation-fund-village. accessed on 06-11-2017.

Debi. 2015. Effect of Accountability, transparency and oversight of budget management with the Value for Money concept. Jom Fecon 2 (2). Through https://media.research.com/media/publications/33876-IDfluence-accountability-transparency-and-property-to-configurationp.pdf. accessed on 09-11-2017.

Dedi Nordiawan; Iswahyudi Sondi Putra; Maulidah Rahmawati. 2012. Government Accounting. Jakarta: Salemba Empat. 
Fajri Azhari. 2017. From Not Transparent to Erroneous Administration. Through http://aceh.tribunnews.com/2017/08/08/from-not-transparentto-errorneous-administration. accessed on 09-11-2017.

Fira (2017) Three Causes of Village Fund manipulation. Through http://surabaya.tribunnews.com/2017/08/07/coordinator-fitra-East Javathis-three-causes-to be-manipulation-fund-village. Accessed 06-112017.

Ganjar Pronowo. 2017. Use the Village Fund. Via https://www.antaranews.com/News/644876/ganjar-takecare-use-fundvillage. accessed on 06-11-2017.

La Asri. 2017. Corruption Agency News. Through https://sultrakini.com/news/I-amn't-ever-signature-to be-itsmanipulation. accessed 06-11-2017.

Mardiasmo. 2009. Public Sector Accounting. Bandung: Andi Opset

Muh Nasran. 2017. Two Former Village Heads Concerning the Village Fund Case. Through http://makassar.tribunnews.com/2017/10/25/two-exhead-village-stuck-case-dana-village-this-word-kasi-intel-kejarijeneponto. accessed 06-11-2017.

Muindro Renyowijoyo. 2008.Public Sector Accounting. Jakarta: Mitra Wacana Media.

Nih Luh Uttari Premananda dan Nih Made Yenni Latriani. 2017. The Effect of Accountability, Transparency, and Budget Participation on Budget Performance in Denpasar City Government. https://pdt.neliti.com/media/publications/131955-ID-p affect-acabilitytransparency and budget participation.pdf. accessed on 06-11-2017.

Pahal Nainggolan. 2017. Kpk Immediately Call Home Affairs Minister and Mende Regarding Village Funds. Via http://www.tribunnews.com/nasional/2017/08/04/kpk-quckly-callmendagri-dan-mendes-pdtt-about-fund-village. accessed on 06-112017.

Rita dan Nurfitriana. 2011. The Effect of Good Governance Implementation on Performance Based Budgeting on the

Vol. 28, No. 2 August 2020

(C) Centre for Indonesian Accounting and Management Research

Postgraduate Program, Brawijaya University 
Government of Aceh. Journal of Accounting and Finance. 1 (2) 93-107. Via https://www.google.com/search?client=firefoxbb\&biw=1366\&bih=659\&ei=zvmrwtixgcvqvase 56 go\&q=rita+me utia+and+nurfitriana+p influ++application+good+governance+of++uscusation ++ performance + on + government + aceh + rita + meutia $\&$ oq $=$ rita + meutia + and + nurfitriana + influence + application + good + governance + to + budgeting + based + performance + on + government + aceh + rita + meutia $\&$ gs_l $=$ psyab $.3 \ldots$

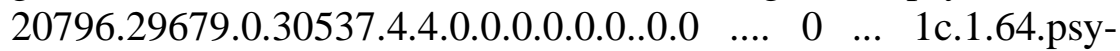
ab..4.0.0 ... 0.1bbkc56kwz8. accessed on 06-11-2017

Risya Umami dan Idang Nurodin. 2017. The Effect of Transparency and Accountability on Village Financial Management. Journal of Scientific Economics. 6 (11). Through: http: //eprints.ummi.ac.id/148/1/6\%20Fluence\%20Transparency \%20 and $\% 20$ Accountability\%20To\%20Management $\% 20$ Management \%20village.pdf. accessed on 09-12-2017.

Setia Untung. 2017. Prosecutors Accompany Thousands of Village Heads to Manage Village Funds. Through http: // law. Rmol.co / read / 2017/08/29/304873 / Attorney - Accompany -Ribuan - Kades - Manage - Funds -Village -. accessed on 11-06-2017.

Taufiq Supriadi, S. Mulyani, Eddy Mulyadi Soepardi, Ida Farida, (2019) Influence of Auditor Competency in Using Information Technology on the Success of E-audit System Implementation, from http://www.ejmste.com/,109529,0,2.html

Taufiq Supriadi, et. al., (2019), The use of information technology of eaudit system on audit quality, from http://produccioncientificaluz.org/index.php/opcion/article/viewFile/24 427/24874

Thjojo Kumolo. 2017. Village Fund Supervision in North Sumatra. Through http://mudanews.com/social -cultural / 2017/10/22 / supervision -danavillage-in-sumut-governor-and-capolda-vicon-together-two-ministers / in access to 06-11-2017. 
64 The Effect of Accountability and Transparency. ....

Tulis S. Melia; Timbul Sinaga; Sylvia Kumala Dewi. 2011.Public Sector Accounting. Jakarta: Semesta Media.

Tirasmart. 2017. Village law. Tangerang: Tsmart.

V. Wiratna Sujarweni. 2015. Village Accounting(Edisi 15). Yogyakarta: New Library Press. 